Maurer School of Law: Indiana University Digital Repository@ Maurer Law

Articles by Maurer Faculty

Faculty Scholarship

1988

\title{
The Changing Face of American Corporate Law Practice
}

John Flood

Indiana University School of Law - Bloomington

Follow this and additional works at: http://www.repository.law.indiana.edu/facpub

Part of the Business Organizations Law Commons, and the Legal Profession Commons

\section{Recommended Citation}

Flood, John, "The Changing Face of American Corporate Law Practice" (1988). Articles by Maurer Faculty. 2514.

http://www.repository.law.indiana.edu/facpub/2514

This Article is brought to you for free and open access by the Faculty Scholarship at Digital Repository @ Maurer Law. It has been accepted for inclusion in Articles by Maurer Faculty by an authorized administrator of Digital Repository @ Maurer Law. For more information, please contact wattn@indiana.edu.

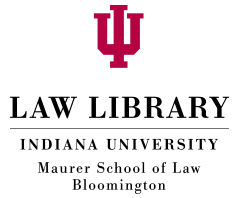




\title{
The Changing Face of American Corporate Law Practice
}

BY

\author{
John FLOOD*
}

\section{Introduction.}

The professions of the 1980 s are completely different from the situation in the 1930s. They are now subject to the norms of business rather than the standards of professionalism. ${ }^{1}$ It is part of the purpose of this article to show that the practice of law has become a business like any other business activity. As a result of this transformation, the norms and standards so often identified with the professions have eroded.

In the next part of the article, I outline some of the demographic changes that have taken place in the legal profession and the reasons for them. This is followed by a discussion of how the large corporate law firm operates, ${ }^{2}$ using two case studies : an example of antitrust litigation and the restructuring of an international corporation.

\section{The Demographic Profile.}

The legal profession in the United States is huge. In 1985 there were 655,191 lawyers, an increase of 21 percent since the beginning

* Assistant Professor of Criminal Justice and Assistant Professor of Law, Indiana University at Bloomington. 
of the decade. ${ }^{3}$ The vast majority of these, over 70 percent, are in private practice. This works out to one lawyer for every 513 members of the population. 4

If we look at the growth of the lawyer population against that of the general population in the U.S. since 1870, we see that from 1870 to 1970 the two have paralleled each other fairly closely, except for two slight rises in 1900 and 1940. In 1870 lawyers numbered 40.000 ; by 1900 the number had nearly tripled to 115.000 ; and by 1970 the number had reached 300.000 , from which point it has skyrocketed. 5

The present legal profession population is by no means a homogeneous mass. The majority of lawyers are in private practice $(70 \%)$, with just under half of them in solo practice. The next largest proportion $(11.2 \%)$ is found in law firms of 51 and above lawyers. 6 These proportions represent a decline in solo practice being compensated by a rise in corporate practice. Table 1 illustrates the changes in these proportions since 1960.

\section{TABLE 1}

Private Practitioners by Practice Setting (Selected Years)

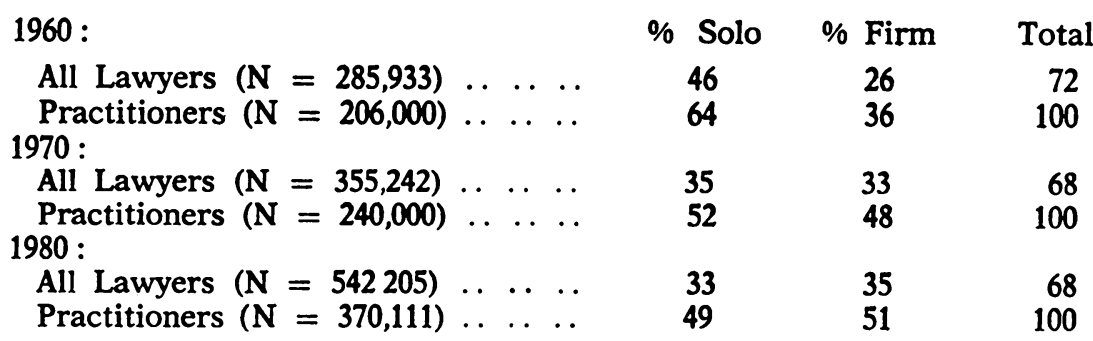

(Reprinted with permission from Barbara A. Curran et al., The Lawyer Statistical Report: A Statistical Profile of the U.S. Legal Profession in the 1980s, Chicago : American Bar Foundation, 1985, p. 14).

Whereas in 1960 solo practice claimed 64 percent of private practitioners, by 1980 more than half were engaged in firm practice.

Why the legal profession has grown so markedly still largely remains unsolved. But to some extent we can speculate that the twin forces of economy and state should have exercised considerable influence - through increased business activity and state regulation of affairs - on this growth in lawyers' numbers.

One of the most startling increases in the past fifteen years has been the rise of the large corporate law firm. Though this type of

$\mathrm{N}^{\circ} 35$ - FÉVRIER 1988 
firm is in a minority in absolute numbers, 7 its influence is overarching. Some firms are now composed of upwards of 400 lawyers : the largest law firm in the world, Baker and McKenzie, with at least 750 lawyers, and offices in most of the major cities of the world, is predicted to expand its numbers into the thousand range by the last decade of the century. These large firms are also huge enterprises in their own right like the corporations they serve. In 1985 Skadden, Arps, Slate, Meagher and Flom had gross revenues of $\$ 169$ million. 8 Since, historically, elite lawyers have been in the vanguard of the development of the American legal profession ${ }^{9}$ - as in forming the Association of the Bar of the City of New York in 1870 and the American Bar Association in 187810 - and typically have clustered in large corporate firms, their importance in both the polity and the economy cannot be overestimated. "The era of " mega-lawyering ", as Marc Galanter has called it, ${ }^{12}$ is qualitatively different from that which preceded it. Mega-law firms are similar in scope and size to the organizations for which they work. ${ }^{13}$

\section{The Structure of Large Law Firms.}

Large law firms are broadly divided along the lines of partners the members and owners of the firm - and associates who are employed by the partnership. ${ }^{14}$ To explain how the system operates I will start with the associates and progress upwards to the partners. ${ }^{15}$ Associates are hired from law school : there is no intervening period of apprenticeship, for shortly after graduating from law school the associate will take the state bar examination and, on passing, will be admitted to the bar. ${ }^{16}$

There is currently a shortage of law school graduates for the elite bar. A firm such as Shadden, Arps, a leader in the mergers and acquisitions field, has 526 lawyers of whom 404 are associates. Skadden, Arps, like other firms, has to compete in a shrinking market of qualified law school graduates; 17 thus salary wars break out. In 1985 when a single firm on Wall Street, Cravath, Swaine and Moore, decided to raise its starting salary to $\$ 65,000$ dollars per annum, other firms, however reluctant, were forced to increase their salaries by similar proportions.

These salary wars create tensions both within firms and between firms. Once such an increase is put into effect, other more senior associates must receive raises also. These increases are paid for in one of two ways : either the extra cost is passed on to clients in the form of higher billing rates, or, to avoid raising billing rates, the 
partners can reduce the size of their draws. Tensions between firms arise when a firm decides not to institute the increase. This can spur an exodus of associates from the firm to others. Even though the increase may happen in only one city, such as New York, it will have effects in other major centres almost immediately. For example, Skadden, Arps has offices in several cities in the United States. Contrary to what most other multi-state firms do, Skadden, Arps pays its associates the same salary regardless of location, which can be significant when New York firms generally pay around $\$ 10,000$ to $\$ 15,000$ per annum more than say Chicago firms.

Firms have two basic ways of remunerating partners, namely, lockstep and merit. The former is remuneration based entirely on seniority without regard to how many clients one controls. Merit pay, however, rewards an individual partner on the basis of how many clients that partner is responsible for and how many hours the partner bills in a year. More and more, firms are switching to the latter mode of remuneration. One reason for this change is that, whilst in previous years partners stayed with the firm they first made partner at, inter-firm mobility has increased tremendously. A firm such as Finley, Kumble, Wagner, Heine, Underberg, Manley, Myerson and Casey is largely composed of lateral hires from other firms on the promise of greater earnings than could be expected under the lockstep tradition.

Firm loyalty is in decline. Firms are also not averse to removing partners who do not generate sufficient work for the firm. Besides those who prove incompetent for one reason or another, those who have specialized in a particular field are especially vulnerable. For example, specialists in air transport regulation have suffered since the Reagan administration deregulated the field.

\section{The Work of Corporate Law Firms.}

What then do large law firms do ? In some respects this is a difficult question to answer for the simple reason that, except for journalistic accounts, few data exist. The kinds of fields of law which these lawyers practice in tell us little about what they actually do. But some sketch of these should be drawn. Most large firms' expertise is in corporate work, e.g., complex contracts, international business, and large-scale litigation. Regardless of the dispute over whether there has in recent years been a litigation explosion, 18 large law firms are geared to running large law suits over a period of years. 
In his book, The Partners, 19 Stewart presents in detail, although somewhat overdrawn in histrionic style, several cases of law firms' involvement in transactions and litigation, e.g., the refinancing of Chrysler, and the IBM anti-trust suit. Both of these case studies demonstrate the peculiar talents of the large corporate law firm.

Large-scale litigation requires intensive use of manpower over extended periods of time. The IBM anti-trust suit involved legions of lawyers in what was effectively one case that lasted for the better part of a decade. ${ }^{20}$ IBM was charged with monopolizing the hardware part of the computer industry under section 2 of the Sherman Act. ${ }^{21}$ The U.S. government suit came on the heels of several private actions instituted by smaller computer firms. ${ }^{22}$ The effect of this multiplicity of suits was to put IBM under siege; it was attacked by different types of organizations spread across the country.

IBM relied on its outside counsel, Cravath, Swaine and Moore, to handle the litigation. Given the multiplicity and geographical diversity of the suits, IBM, through Cravath, had to employ other law firms to act as local counsel, though at all times Cravath held the position of lead counsel which would devise and control the strategies adopted in the litigation. Cravath set up its litigation headquarters at the White Plains head office of IBM. As the cases progressed, more and more associates were drafted onto the IBM case.

The private and government actions against IBM effectively interlocked; a win in one would redound to the benefit of the other. When the first suit, a private one brought by Control Data Corporation (CDC), was started, Cravath replied with a series of discovery requests Cravath gave CDC's lawyers more documents than they could absorb. As Stewart points out, there was a crucial difference in the methods of the two sets of lawyers. Cravath had known what was in each of the documents it had produced; conversely, CDC's lawyers did not read every document they handed to Cravath. When the Cravath team combed the CDC documents, they discovered evidence of a plan by CRC to join a consortium that would have acted to fix prices and arrange markets to suborn IBM. When CDC's lawyers realized the information Cravath possessed, they agreed to settle.

At this stage only two partners and four associates were assigned to the litigation. When Cravath lost one of the cases against Telex with a $\$ 350$ million verdict against IBM, IBM insisted that more lawyers be put on to the cases. In all, there were three partners; about 
twenty associates, and a considerable amount of help from IBM. The verdict against IBM stimulated the government into pressing forward its case. As discovery progressed, Cravath took somewhere in the region of a thousand depositions of witnesses. The government asked for 760 million IBM documents. Although the government sought a trial date in 1974, it was not until 1976 that the trial proper began, seven years after the U.S. Attorney General signed the complaint. Part of Cravath's strategy was to set up an office in the Southern District of New York near the trial court and to form teams around the broad issues of the case, such as " market structure " and " acts and practices, " which would prepare the appropriate parts of the case as those witnesses came to testify. Only the partners, however, were allowed to speak in court.

While the government case was in progress, so were other private suits against IBM. Cravath was forced to set up satellite teams constructed out of its government team. These satellite teams travelled around the country as and when trials began. Some of these private actions were on trial for several months. For example, a suit brought by Calcomp lasted for ten months. Perhaps this is one of the salient points about this type of litigation; it drags on for years. Again, for example, one of the government witnesses spent a total of seven months on the witness stand.

By 1980, Cravath had won all the private cases, either at trial or on appeal, and by 1981 it had presented its case in the government matter. At this time the Reagan administration had taken over from that of President Carter. And it was characterized by a libertarian, free-market economic policy, in contrast to the previous administration's intervention into the marketplace. Rather than drag the case out interminably the government entered settlement discussions, and in 1981 the case was dismissed.

Even within a large firm such as Cravath - currently with 230 lawyers - such an intensive and extensive series of interconnected cases takes an enormous toll on a law firm. There is a danger that a single client comes to dominate the firm. And as client loyalties are becoming diluted as more legal jobs are being taken in-house by corporations, to rely one one or a few large clients can prove risky. Moreover, a single case like the IBM suit can distort the growth of a law firm, for while the case is in progress many associates are hired into the litigation department, but there is a danger that once the case is finished there may be a shortage of work for them. Some of these dangers reappear in the next case study of Chrysler Automotive Corporation's restructuring.

$\mathrm{N}^{\circ} 35$ - FÉVRIER 1988 


\section{ii. Restructuring and Bankruptcy.}

At the end of the 1970s Chrysler was facing imminent collapse. The automobile company had not changed its production from heavy, thirsty motor cars suitable to the period of cheap gasoline to lighter, more efficient models. As a result the company's inventory was too high and its sales were dismally low; and in 1979 Chrysler lost $\$ 1.1$ billion dollars. ${ }^{24}$ In order to prevent a massive bankruptcy, Congress passed the Chrysler Corporation Loan Guarantee Act of 1979. The act stipulated that if certain conditions were met, the government would guarantee funds for Chrysler.

To shepherd the company through the labyrinth of these conditions, Chrysler hired Debevoise, Plimpton, Lyons and Gates (now Debevoise and Plimpton), a large Wall Street law firm. The central requirement of the restructuring of Chrysler was that all of Chrysler's and Chrysler Finance Company's (a subsidiary that financed customer loans) debtors relinquish the primacy of their interests in favor of the government. Manufacturers Hanover Corporation, a large bank, was the main debtor, with over $\$ 55$ million in debts outstanding. But there were also around 400 other banks, large and small, in the U.S., Canada, Europe, and Japan which were owed large sums of money. Any one of them could claim a default on Chrysler's part and force Chrysler into bankruptcy, which would inflict huge losses on all creditors. It was in everyone's interest to keep Chrysler afloat.

Debevoise was taken on in part because it had no major bank as a client and was therefore free of any potential conflicts of interest. As with the IBM anti-trust litigation, the Chrysler restructuring would require an enormous committment of labor from Debevoise. Unlike Cravath, Debevoise had a firm rule that no single client could claim more than 15 percent of the firm's resources : it was obvious to the partnership that Chrysler would breach this rule. Neverthleless, the law firm agreed to be lead counsel for Chrysler.

In negotiating with banks in four parts of the world, Debevoise encountered many cultural and political problems. The Japanese concept of honor demanded that Japanese banks help Japanese corporations when they were in trouble. Thus the Japanese failed to understand why the American banks were not assisting Chrysler. They suspected the government of providing better conditions for American banks than Japanese ones. The Canadian banks, too, were suspicious, an attitude hardened by many years of Canadian mistrust of the United States. The Canadian banks' loans were secured by rights to the assets of Chrysler's subsidiary, unlike most of the American banks' loans which were unsecured. The Canadian banks 
were determined to keep this advantage. Their first step was to freeze $\$ 50$ million dollars of Chrysler's deposits in Canada. The American banks were convinced that the Canadians were receiving an unfair benefit and Debevoise had to persuade them not to scuttle the entire restructuring because of the freeze. Eventually, Debevoise had to assign a senior partner full-time to the Canadian negotiations.

The only true bargaining counter Debevoise possessed was the threat that Chrysler would go bankrupt, thereby defaulting on its loans. At certain stages in the negotiations with the banks and the U.S. Treasury, the threat appeared imminent without the willing agency of Chrysler. Chrysler was fast running out of money. A transfusion of $\$ 100$ million from Peugeot, although having the appearance of a loan, had to be dressed as a sale; Peugeot could not have first priority on the stock which the "loan " was secured against since the U.S. government had priority over all others. Added to these difficulties was the problem Debevoise had in determining the exact size of Chrysler's likely loss for the year. Every time the figure was established, it changed for the worse, but some degree of accuracy was essential to satisfy both the Treasury and the Securities and Exchange Commission that the prospectus would be truthful.

When Debevoise reached a tentative agreement with the banks and the Treasury, it began the drafting of the documents that would tie the entire deal together. One hundred and fifty lawyers from ten law firms worked on the drafting.

Though the great majority of the banks agreed to the terms, three attempted to go their own route by filing lawsuits which Debevoise had to delay and finally to invoke the help of the Treasury Secretary to dispel the banks' fears. Piece by piece, the transaction was coming to a close : the European and Japanese banks agreed, but the Canadian banks would not. Ultimately, it took the efforts of the two governments to reconcile the differences.

When the loan guarantee application was accepted by the Treasury, the closing could occur. Since this closing would require hundreds of signatories signing thousand of documents, it was spread over three law firms in Wall Street.

\section{Discussion and Conclusion.}

The lawyers in the case studies here are highly sophisticated technicians. And this is the core of mega-lawyers' work. They construct complex transactions so that every contingency is accounted for. It may be drafting a series of interlocking documents as in the Chrysler case; or it may be manipulating procedural matters so as to confound

$\mathrm{N}^{\circ} 35$ - FÉRRIER 1988 
the opposition as in the IBM litigation. Cravath and Debevoise could quickly introduce large quantities of manpower to cope with exigencies. This ability can easily overwhelm, and is often intended to, the opposing parties' lawyers, whether they be private practitioners or government lawyers. Either a problem can be dragged out for an extended time as in IBM, or it can be telescoped as in Chrysler.

These two case studies illustrate the capacities of and the exigencies faced by large corporate law firms. Individual lawyers and the firms they work for must tolerate immense pressures over extended lengths of time. In both situations discussed, the firms were profoundly affected by the changes wrought by the nature of these cases. Both firms breached intra-firm rules - creating separate offices for IBM and committing more than 15 percent of the firm's resources to Chrysler - that had guided their development. But such firms as Cravath and Debevoise exist to serve the needs of capital and though they may desire to retain a certain status quo ante, they are, however, not immune to the economic pressures that capital exerts, for good or ill. Yet business and the professions are held to different standards and treated differently by the state. But given the intricate web of connections that exist between the professions - especially those of law and accountancy - and commerce and industry, it is surprising perhaps that the professions have managed to maintain for so long the idea that they are unsullied by the norms of business and consequently should possess the privilege of regulating themselves without community interference. ${ }^{25}$

In some respects large law firms are coming to resemble their clients. Whereas law firms grew by taking in a class of associates each year, training them, and eventually conferring the mantle of partner on them, they now merge with and take over other law firms in order to acquire missing expertise and extend their client bases. ${ }^{26}$ Partners are raised by other firms for their client-getting abilities. Firms, which were once considered stable entities as partners remained with the same firm for life, are now becoming shifting congeries of profit centres that will exist as long as expedient.

Who then are lawyers beholden to ? Where do their fiduciary interests lie? The answer may not be easily sought : though lawyers move from firm to firm with their clients, they use the client base they have established as a resource to assist them in gaining and maintaining power within the context of the firm. Power gives them the ability to claim more money, more lawyers working on their client matters, and to set policy in the firm. There is an intertwining of needs and benefits that feed into and reinforce each other. One commentator expressed the sentiment thus : 
The large law firm has now become an American institution in itself. Lawyers in big firms are no longer accountable to individual clients. Rather, they are accountable to their law firm. Law firms are the entity, not the individual. The objective of the large law firm is simply to make money and to grow bigger in order to make more money. To a large extent, the client has been left out in the cold. 27

If such is the case, and the evidence strongly suggests that the commercialization of the elite bar is taking place, the privileges accorded to the traditional concept of the bar are no longer appropriate and the conventional modes fo community response to the legal profession are historically out of kilter with the modern reality.

To some extent, external regulation of the bar has already occurred. Both the Internal Revenue Service and the Securities and Exchange Commission have issued rules on what constitutes proper behavior for those attorneys who practice before them. Moreover, they now take disciplinary action against lawyers who infringe their practice rules. ${ }^{28}$ External regulation of this kind, however, is anathema to the concept of a self-regulating profession. But within the confines of the bar itself, the trends show a disquieting move. Complaints, involving lawyers' fees, to state bar disciplinary agencies jumped from 39,000 in 1984 to 54,000 in 1985.29

Finally, though the case studies only hinted at this phenomenon, the practice of corporate law has become heavily routinized. The documents drafted by the teams of lawyers at Debevoise were mostly taken from standard forms everpresent on the word processor. Although changes are made to fit the specific situation, no document is drafted from point zero. Much of the discovery process involving many highly priced associates entails examining boxes of intra-company memoranda to determine whether they should be seen by the other side, which requires no legal skills. Much of this kind of work is now performed by paralegals who are considerably cheaper than associates. ${ }^{30}$ The general counsel to Arthur Young and Company, one of the Big Eight accounting firms, asserted : "While I cannot empirically prove my next statement, in twenty years of having been exposed to the law, I believe that 65 percent of what most lawyers do can be done by non-lawyers and should be done by non-lawyers whether that is a computer, a paralegal or some other support staff. » 31

Large law firms, corporate practice, mega-lawyering, whatever we call the Leviathan, is a response to the needs and contingencies of capitalism in the late twentieth century. But the ethos of professionalism that Carr-Saunders and Wilson ${ }^{32}$ could write about so securely

$\mathrm{N}^{\circ} 35$ - FÉVRIER 1988 
in the 1930s no longer has any meaning within the present organization of law practice. New forms demand new modes of arrangement and theorizing. Perhaps the words of Carl Liggio, are an apposite epilogue to this essay: Most lawyers think of themselves first and foremost as lawyers, when in reality, they are a very small part of a much larger profession or industry. That industry is the industry of information management ${ }^{33}$.

\section{NOTES}

* I would like to thank Lucinda J. Peach and Mary L. Coyne for their comments on earlier drafts of this article.

1. For the story medicine see Paul Starr, The Social Transformation of American Medicine: The Rise of a Sovereign Profession and the Making of a Vast Industry, New York: Basic Books, 1982.

2. Certain words are used interchangeably here. Large law firms are considered the elite members of the bar by the nature of their clients and the work they do for them. Sometimes I use corporate law firm instead of large law firm; it is to emphasize that the firms work for corporations.

3. Barbara A. Curran, Supplement to the Lawyer Statistical Report: the U.S. Legal Profession in 1985, Chicago: American Bar Foundation, 1986.

4. Id.

5. Terence C. Halliday, «Six Score and Ten: Demographic Transitions in the Legal Profession, 1850-1980, " Law and Society Review, vol. 20, p. 53, 1986.

6. Op. cit., Curran.

7. In 1985 law firms of 51 lawyers or more accounted for 1.2 percent of all firms $(\mathrm{N}=42,318)$, but the same firms employed 11.2 percent of all private practitioners. Curran, Supplement, op. cit., pp. 45.

8. "The AmLaw 75: America's Seventy-Five Highest Grossing Firms, » American Lawyer, November 1986, chart.

9. See, e.g., Robert W. Gordon, \& Legal Thought and Legal Practice in the Age of American Enterprise, 1870-1920, " in Gerald L. Geison, ed., Professions and Professional Ideologies in America, Chapel Hill, N.C.: University of North Carolina Press, 1983, p. 70. 
10. See Roscoe Pound, The Lawyer from Antiquity to Modern Times, St. Paul, Minn.: West Publishing Co., 1953, p. 254 passim.

11. This is especially true as we enter the postmodern age of fragmented communities no longer tied together by common interests. See Jean-François Lyotard, The Postmodern Condition: A Report on Knowledge, Minneapolis : University of Minnesota Press, 1983.

12. Marc Galanter, «Mega-Law and Mega-Lawyering in the Contemporary United State, " in Robert Dingwall and Philip Lewis, eds., The Sociology of the Professions: Lawyers, Doctors and Others, New York: St. Martin's Press, 1983, p. 152.

13. Cf. John P. Heinz and Edward O. Laumann, Chicago Lawyers: The Social Structure of the Bar, New York: Russell Sage Foundation and Chicago: American Bar Foundation, 1982; and Robert L. Nelson, Practice and Privilege: The Social Organization of Large Law Firms, unpublished Ph. D. dissertation, Sociology Northwestern University, 1983.

14. Black's Law Dictionary (Rev. 4th ed.) defines « partnership » as: "A volluntary contract between two or more competent persons to place their money, effects, labor, and skill, [...] in lawful commerce or business, with the understanding that there shall be a proportional sharing of the profits and losses between them."

15. Besides these two categories, law firms hire enormous staffs of paralegals, law clerks, secretaries, librarians, messengers, and accountants.

16. Note that each state administers its own bar examination and determines the rules for eligibility of entry. In most states passing the examination entitles one to begin practice immediately. Vermont, for example, requires several months of clerking in an attorney's office.

17. Members of the elite bar avoid taking graduates from the lower ranks of law schools.

18. Cf. Marc Galanter, "Reading the Landscape of Disputes: What We Know and Don't Know (And Think We Know) About Our Allegedly Contentious and Litigious Society, "UCLA Law Review, vol. 31, 1983, p. 4.

19. James B. Stewart, The Partners: Inside America's Most Powerful Law Firms, New York: Simon and Schuster, 1983.

20. Stewart, op. cit., "IBM : Cravath, Swaine and Moore, pp. 53-113.

21. 15 U.S.C. s. 2 (1890).

22. Private actions are brought under section 1 of the Sherman Act. For a more prosaic rendition of an anti-trust case see, Dorsey Ellis, Jr. and James E. Meeks, Trial of an Anti-Trust Case, Chicago: American Bar Association Sections of Litigation and Antitrust Law, 1977.

23. Discovery is the process whereby each side to a dispute is required by law to hand over copies of documents requested by the other side. A lawyer's work product is usually exempted. Document production is often a precursor to deposing potential witnesses in a case. The theory behind discovery is to accelerate the suit and to avoid surprise at trial : it removes again in theory, the game element from a trial, but as we shall see, it frequently introduces its own game elements. See, also, Wayne D. Brazil, «Views from the Front Lines : Observations by Chicago Lawyers about the System of Civil Discovery, A American Bar Foundation Research Journal, $\mathrm{n}^{\circ} 4$, p. 217, 1980.

N 35 - FÉVRIER 1988 
24. Stewart, op. cit., « Chrysler: Debevoise, Plimpton, Lyons and Gate, pp. 201-44.

25. An interesting, but related, sideshow was presented during the recent federal investigation of the state judiciary (* Operation Greylord »), in Cook County, Illinois. Every single lawyer who gave information about corrupt activities did so only after he was theatened with prosecution. None volunteered information. See also Jerold S. Auerbach, Unequal Justice: Lawyers and Social Change in Modern America, New York: Oxford University Press, 1976; and James C. Foster, The Ideology of Apolitical Politics: The Elite Lawyers' Response to the Legitimation Crisis in American Capitalism: 1870-1920, New York: Associated Faculty Press, 1986.

26. See Mark Stevens, « Breaking “The Code": Finley, Kumble and the Cult of the Rainmakers, > in Power of Attorney: The Rise of the Giant Law Firms, New York : McGraw-Hill, 1987, pp. 37-68.

39. Peter M. Brown, « Remarks : The Changing Nature on the Practice of Law, * Federal Bar Council, 1984 Bench and Bar Conference Proceedings, Dorado, Puerto Rico, p. 90.

28. E.g., see Paul J. Routh, «Liabilities of a Tax Preparer: An Overview, * Capital University Law Review, vol. 13, pp. $479-519$ (1984).

29. U.S. News, March 2, 1987, p. 27. No breakdown as to size of practice is supplied, however.

30. Quintin Johnstone and Martin Wenglinsky, Paralegals: Progress and Prospects of a Satellite Occupation, Westport, CT : Greenwood Press, 1985.

31. Carl Liggio, « Remarks: The Changing Nature of the Practice of Law, * Federal Bar Council, 1984 Bench and Bar Conference Proceedings, Dorado, Puerto Rico.

32. Voir note 1.

33. Carl Liggio, op. cit., p. 106. 